\title{
Medical Association Rule Mining Using Genetic Network Programming
}

\author{
Kaoru Shimada Student Member (Waseda University, k.shimada@ruri.waseda.jp) \\ Rouchen Wang Non-member (Waseda University, zyaku@akane.waseda.jp) \\ Kotaro Hirasawa Member (Waseda University, hirasawa@waseda.jp) \\ Takayuki Furuzuki Member (Waseda University, jinglu@waseda.jp)
}

Keywords: Evolutionary Computation, Genetic Network Programming, Data Mining, Association Rule, Classification

An efficient algorithm for building a classifier is proposed based on an important association rule mining using Genetic Network Programming (GNP). The proposed method measures the significance of the association via the chi-squared test. Users can define the conditions of important association rules for building a classifier flexibly. The definition can include not only the minimum threshold chi-squared value, but also the number of attributes in the association rules. Therefore, all the extracted important rules can be used for classification directly. GNP is one of the evolutionary optimization techniques, which uses the directed graph structure as genes. Instead of generating a large number of candidate rules, our method can obtain a sufficient number of important association rules for classification. In addition, our method suits association rule mining from dense databases such as medical datasets, where many frequently occurring items are found in each tuple. In this paper, we describe an algorithm for classification using important association rules extracted by GNP with acquisition mechanisms and present some experimental results of medical datasets.

Association rule mining is the discovery of association relationships or correlations among a set of attributes in a database. Association rule in the form of 'If $X$ then $Y$ $(X \Rightarrow Y)$ ' is interpreted as 'database tuples satisfying that $X$ (antecedent) are likely to satisfy $Y$ (consequent)'. In this paper, we deal with a given consequent specified by the user. Let $A_{i}$ be an attribute (item) in a database and its value be 1 or 0 , and $Z$ be the set of class labels. The proposed method extracts the following association rules: $\left(A_{m}=1\right) \wedge \cdots \wedge\left(A_{n}=1\right) \Rightarrow(Z=C),(C=0,1,2, \ldots, K)$ Attributes in the database correspond to judgement nodes in GNP, respectively. We are able to represent the connection of nodes as association rules and nodes are reused and shared with some other association rules because of GNP's feature.

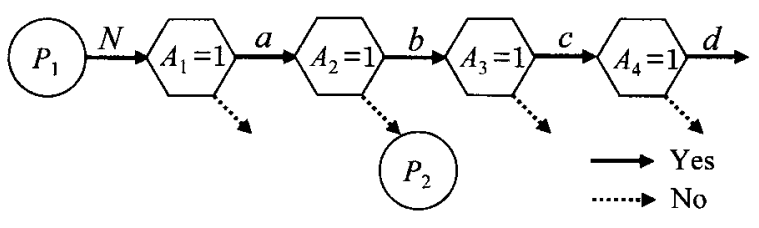

: Judgement Node,

: Processing Node

Fig. 1. GNP for association rule mining

GNP examines the attribute values of database tuples using judgement nodes and calculates the measurements of association rules using processing nodes. The measurements include support (frequencies of occurring patterns) and confidence (strength of implication). Fig.1 shows a basic structure of GNP. $P_{1}$ is a processing node and is a starting point of association rules. $N$ is the number of total tuples, and $a, b, c$ and $d$ are the numbers of tuples moving to Yes-side at each judgement node. In addition, each judgement node examines the ' $Z=C$ '. For example, in Fig.1, the number of tuples ' $b$ ' indicates support $\left(\left(A_{1}=1\right) \wedge\left(A_{2}=1\right)\right)$, and GNP calculates $\operatorname{support}\left(\left(A_{1}=1\right) \wedge\left(A_{2}=1\right) \wedge(Z=1)\right)$ at the same time. Using $\operatorname{support}\left(\left(A_{1}=1\right) \wedge\left(A_{2}=1\right) \wedge(Z=1)\right)=b(Z=1)$, support and confidence of rule $\left(A_{1}=1\right) \wedge\left(A_{2}=1\right) \Rightarrow(Z=1)$ are obtained $b(Z=1) / N$ and $b(Z=1) / b$, respectively. As $\operatorname{support}(Z=1)$ is known in advance, we also can obtain the chi-squared value of the rule $\left(A_{1}=1\right) \wedge\left(A_{2}=1\right) \Rightarrow(Z=1)$. Extracted rules are stored in a pool all together through the generations. The rules can be used for classification directly, because they satisfy the conditions of importance. We propose two methods to build a classifier from the extracted rules, and have performed experiments and estimated the performance. 


\title{
遺伝的ネットワークプログラミングを用いた医療相関ルールの抽出
}

\author{
学生員 嶋田 香* 非会員 王 若晨* \\ 正 員 平澤 宏太郎* 正 員 古月 敬之*
}

\author{
Medical Association Rule Mining Using Genetic Network Programming \\ Kaoru Shimada*, Student Member, Rouchen Wang*, Non-member, Kotaro Hirasawa*, Member, \\ Takayuki Furuzuki*, Member
}

\begin{abstract}
An efficient algorithm for building a classifier is proposed based on an important association rule mining using Genetic Network Programming (GNP). The proposed method measures the significance of the association via the chi-squared test. Users can define the conditions of important association rules for building a classifier flexibly. The definition can include not only the minimum threshold chi-squared value, but also the number of attributes in the association rules. Therefore, all the extracted important rules can be used for classification directly. GNP is one of the evolutionary optimization techniques, which uses the directed graph structure as genes. Instead of generating a large number of candidate rules, our method can obtain a sufficient number of important association rules for classification. In addition, our method suits association rule mining from dense databases such as medical datasets, where many frequently occurring items are found in each tuple. In this paper, we describe an algorithm for classification using important association rules extracted by GNP with acquisition mechanisms and present some experimental results of medical datasets.
\end{abstract}

キーワード : 進化型計算, 遺伝的ネットワークプログラミング, データマイニング, 相関ルール , クラス分け

Keywords: Evolutionary Computation, Genetic Network Programming, Data Mining, Association Rule, Classification

\section{1. はじめに}

相関ルール ${ }^{(1)}$ は , データマイニング ${ }^{(2)}$ の一手法であり， 関係データベースにおいて属性 (アイテム) 間にみられる 関係に注目したものである。相関ルールは，「X $X Y\lrcorner$ の形 で表現され， $X, Y$ に属性に関する条件が入る。これは，あ るレコードが $X$ (前提部) を満たせば $Y$ (結論部) も満たすと いうような事実を表現しようとするものである。Agrawal ら (3) によって提案された相関ルール抽出のアルゴリズム (アプリオリ法) によれば , サポート (レコードの出現頻度) と確信度 (ルールを構成する属性の結びつきの強度) を指 標として，ユーザの指定した基準を満たす相関ルールを導 出することができる。しかしながら，密なデータベース ${ }^{(4)}$ を扱うなどのアイテムの出現頻度が高くなる場合には計算 量か指数関数的に増えること, 計算量を抑えようとすると

\footnotetext{
* 早稲田大学大学院情報生産システム研究科

干 808-0135 福岡県北九州市若松区ひびきの 2-7

Graduate School of Information, Production and Systems,

Waseda University

2-7, Hibikino, Wakamatsu-ku, Kitakyushu, Fukuoka, 8080135, Japan
}

重要なルールを失うなどの問題がある。また , 相関ルールの 興味深さの指標に関する問題も指摘されている。Brin ら (5) はサポートと確信度の両者が, どの程度の值を満たせば興 味深いルールであると判断できるかという客観的な基準は 存在せず，これらは相関ルールの重要度の判断には適当で ないと指摘し, 統計学で用いられる $\chi^{2}$ 值を指標とする方 法に注目している。しかし, $\chi^{2}$ 值を算出する際に必要とな る相関ルールの前提部・結論部のサポートをどのように効 率よく扱うかという問題があり，相関ルールを構成する属 性数が増加した場合には対応が困難となる。

これらの問題点を改善すべく, 我々は進化論的計算手法 の 1 つである遺伝的ネットワークプログラミング (Genetic Network Programming, GNP) ${ }^{(6) \sim(8)}$ を用いた相関ルール の抽出方法 ${ }^{(9)(10)}$ を提案している。GNP は, 相関ルール抽 出への応用にあたって有益と考えられる次のような特徵を もっている。

・グラフ上のノードの再利用／共有が可能であり, 探索 空間を有効に構成できる。

• GNP における 1 つのノードが相関ルールの 1 つの属 性を表し，ノードの連結と光の遷移を相関ルールと対 応させることができる。 
・興味深い相関ルールを抽出することができた場合, 光 のルールの一部を遺伝的操作によって変化させ , さら なるルールの探索が可能である。

GNP を用いた相関ルール抽出方法では, 相関ルールの結 論部を構成する属性を自動的に設定するものと，結論部の 属性を予め指定して抽出するものがある ${ }^{(9)}$ が , これらの手 法には, 次のような特徵がある。

・相関ルールのサポートと確信度を GNP を用いて直接 算出することができる。統計学で用いられる $\chi^{2}$ 值の 算出についても GNP の構造上の特性を活かして直接 行うことができる。

・アプリオリ法のように頻出アイテム集合のすべてのサ ポートを記憶しておく必要はないため, 各レコードに 多くのアイテムが含まれる密なデータベース ${ }^{(4)}$ からの ルール抽出が可能になる。

・ユーザが定義した興味深さの指標に基づいた相関ルー ルを抽出する。興味深さの定義には相関ルールの $\chi^{2}$ 值 やルールを構成する属性数を含めることができる。ま た，GNP の適合度は，興味深さの指標を反映した関 数を設定することができる。

・通常の進化論的計算手法にみられるような最良の個体 （解）を発見することを目的とはせずに，GNP の各世 代の個体が抽出した興味深い相関ルールを相関ルール ライブラリーに蓄積する方式である。すべてのルール を抽出することはできないが，指定した世代終了時点 で蓄積されている興味深い相関ルールをユーザは活用 することができる。

ところで, 相関ルールを用いて分類や予測を行う手法も 提案されている(4)(11)。これらは, 結論部を予め指定して抽 出した相関ルールを利用してクラス分け問題を扱う。従来 手法においては, サポートと確信度を指標として相関ルー ルを抽出した後, これらの相関ルールから, 分類に適した 相関ルールの集合を作成して分類を実行している。このた め, 信頼度の高い分類を行うための相関ルールの集合の作 成方法か課題となる。我々の提案している GNPを用いた 相関ルール抽出では， $\chi^{2}$ 值の指標を含むユーザの定義した 興味深い相関ルールのみが抽出されるため, 抽出された相 関ルールを直ちに分類に用いることができる。

本論文では, 結論部の属性を予め指定した相関ルールを GNP を用いた興味深い相関ルール抽出法によって抽出し， さらに抽出された相関ルールを用いた分類手法を提案する。 GNP を用いた相関ルール抽出法は, 密なデータベースか らの相関ルール抽出に適すること, 興味深さの指標に $\chi^{2}$ 値 を用いていること，などの特徵から医療系のデータベース への応用が有効であるため, 実際の医療系のデータセット を用いて提案手法の評価を行っている。

本論文の構成は以下の通りである。第 2 章で GNP の基 本構成，遺伝子表現および進化方法について概説する。ま た，第 3 章はデータマイニングの一手法である相関ルール と指標について，さらにこれを用いた分類問題について説
明する。第 4 章では, GNP を用いた興味深い相関ルール 抽出の方法と抽出されたルールを用いた分類方法を提案し， 第 5 章はシミュレーション結果と光の考察を述べる。第 6 章はまとめである。

\section{2. 遺伝的ネットワークプログラミング（GNP）}

本章では遺伝的ネットワークプログラミング (Genetic Network Programming，GNP) ${ }^{(6) \sim(8)}$ について概説する。 GNP は, 進化型計算手法の 1 つであり，ノードをネット ワーク状に接続することによって，プログラムの自動生成 を行う。

GNP の基本構造を図 1 に示す。GNP は, 判定ノード (Judgement node), 処理ノード (Processing node) の 2 種類のノードからなり，有向グラフの構造になっている。 ノード間の接続と遷移によりプログラムが生成される。判 定ノードは判定内容が記載されているノードであり，入力 に従って，予め設計者の用意したとおりに分㞳を行う。処 理ノードは，GP の終端記号に対応づけることができるが， 環境に対して行う処理など，扱う問題に応じて設計者の用 意した処理内容か記載されている。図 1 において, $J_{n}$ は判 定ノード用のライブラリーに記載されている $n$ 番目の判定 内容 (関数) を示しており, 同樣に $P_{n}$ は処理ノード用のラ イブラリーに記載されている $n$ 番目の処理内容 (関数) を 示している。図 1 の $S$ は初期起動ノードでありただ 1 度だ け使用される。

GNP の遺伝子表現は, 全ノードに弚れ固有なノー ド番号 $i$ が与えられており，ノード番号 $i$ の遺伝子の構成 が図 2 で示されている。図 2 の各変数を以下に示す。

- $N T_{i}$ : 種別遺伝子

$(0:$ 初期起動ノード, $1:$ 判定ノード, $2:$ 処理ノード $)$

- $I D_{i}:$ 判定 ·処理内容遺伝子

(GNP のライブラリーに示されている判定，処理内 容のコード番号)

- $C_{i j}$ : 接続遺伝子

(ノード番号 $i$ から分岐する $j$ 番目のノード番号)

また，GNP の進化方法として，次に示す通常の方法を使 用する。

- 突然変異 : 親個体のノードの接続先の変更とノード関 数の変更を確率的に行い子個体を生成する。

・交叉 : 親個体間の対応するノードの接続先とノード関 数を確率的に交換し子個体を生成する。

・再生:エリート保存選択，トーナメント選択を併用する。

3. 相関ルール

本章では,データマイニングの手法の1つである相関ルー ル (association rule) ${ }^{(1)(2)}$ と相関ルールを用いた分類につ いて概説する。

〈3. 1〉 相関ルールとサポート・確信度 関係データ ベースにおいて，1 つのレコードがある条件を満たすか否 かの判断をテストとよぶことにする。 $X$ と $Y$ をテストとす 


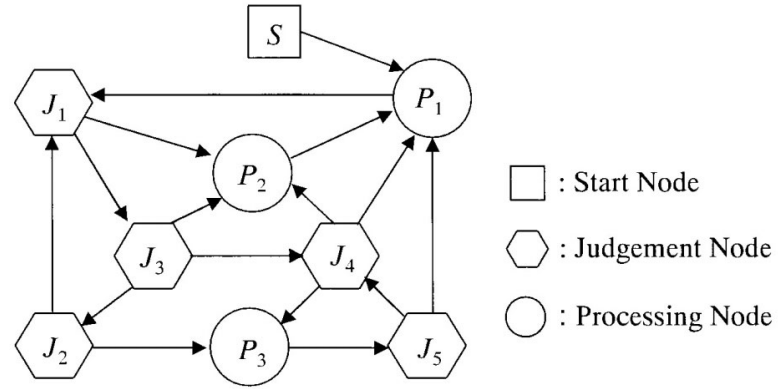

図 1 GNP の構造

Fig. 1. Basic structure of GNP.

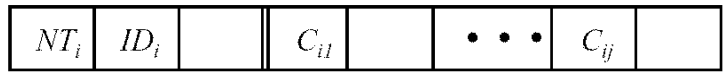

図 2 GNP の遺伝子構造 (ノード番号 $i$ )

Fig. 2. Gene structure of GNP (node $i$ ).

るとき，相関ルールとは， $X \Rightarrow Y$ と記述できる関係であ り,「あるレコードが $X$ を満たせば $Y$ も満たす」というよ うな事実を表現しようとするものである。 $X$ は相関ルール の前提部 (antecedent)， $Y$ は結論部 (consequent) とよば れ，データベース中で， $X$ と $Y$ の両方を満たすレコードの 割合を相関ルールのサポート (support) , $X$ を含むレコー ドのうち $Y$ を含むものの割合を確信度 (confidence) とい う。例えば表 1 において,$(A=1) \wedge(C=1) \Rightarrow(D=1)$ のサポートは 0.25 , 確信度は 0.5 である。

サポートと確信度は, 相関ルールの重要度を評価する指 標として用いられている。Agrawal ら ${ }^{(3)}$ は, サポートと 確信度が炎れ光れユーザによって与えられたしきい值以上 である相関ルールを興味深いルールとして抽出するアプリ オリ法 (apriori algorithm) を提唱している。アプリオリ法 は, サポートと確信度の条件を満たす頻出アイテム集合を すべて抽出するため，この集合の数が巨大になる場合には コンピュータの処理能力の問題が生じてくる可能性もある。 アプリオリ法の効率を向上させるために , ハッシュを用い るなど多くの手法 ${ }^{(12)}$ が提案されている。

〈3. 2〉 相関ルールとカイ 2 乗值 相関ルールのサポー 卜と確信度の両者が, どの程度の值を満たせば興味深いルー ルであると判断できるかという客観的な基準は存在せず，前 提部と結論部の相関関係の判断には適当でないとの指摘が Brin ら (5) によってなされている。Brin らは統計学で用い られる $\chi^{2}$ 值 (chi-squared) を指標とする方法に注目してお り，これを用いたアルゴリズムを提唱している。相関ルー ル $X \Rightarrow Y$ において $, X, Y$ および $X \wedge Y$ を満たすレコー ド数の割合 (サポート) を光れ光れ $x, y$ および $z$ とし，レ コードの総数を $N$ とする。表 2 は， $X$ と $Y$ が独立してお り同じレコード内に含まれるのが偶然であると仮定したと きの期待度数 (上段) と，実際のレコード数である観測度 数 (下段) を示したものである。この分割表に対して，
表 1 データベースの例

Table 1. An example of database.

\begin{tabular}{c|cccc}
\hline$T I D$ & $A$ & $B$ & $C$ & $D$ \\
\hline 1 & 1 & 0 & 1 & 0 \\
2 & 0 & 1 & 1 & 1 \\
3 & 1 & 1 & 1 & 1 \\
4 & 0 & 1 & 0 & 1 \\
\hline
\end{tabular}

表 2 分割表

Table 2. The contingency of $X$ and $Y$.

\begin{tabular}{c|c|c|c}
\hline & $Y$ & $\neg Y$ & $\sum_{\text {row }}$ \\
\hline$X$ & $N x y$ & $N(x-x y)$ & $N x$ \\
& $N z$ & $N(x-z)$ & \\
\hline$\neg X$ & $N(y-x y)$ & $N(1-x-y+x y)$ & $N(1-x)$ \\
& $N(y-z)$ & $N(1-x-y+z)$ & \\
\hline$\sum_{c o l}$ & $N y$ & $N(1-y)$ & $N$ \\
\hline
\end{tabular}

$$
T=\sum_{\text {全セル }} \frac{(\text { 観測度数 }- \text { 期待度数 })^{2}}{\text { 期待度数 }} \ldots \ldots \ldots \ldots
$$

とすると, $T$ は自由度 1 の $\chi^{2}$ 分布に従うことが知られて いる。これに表 2 の各値を代入すると，

$$
T=\frac{N(z-x y)^{2}}{x y(1-x)(1-y)} .
$$

となる。Tの值によって,$X$ と $Y$ の相関を判断するが，あ る有意水準を定めて相関ルールの取捨を行うことができる。 例えば, 有意水準を $5 \%$ とすると $T>3.84,1 \%$ とすると $T>6.63$ であれば光の相関ルールは興味深いものとして抽 出できる。

〈3. 3〉 相関ルールを用いた分類 相関ルールを分類問 題に応用する場合には, 訓練用データベースから抽出され た相関ルールの集合を用いて分類がなされる。通常の相関 ルールの抽出とは異なり，結論部を分類したいクラスに制 限してルールの抽出を行うため, これに特化した抽出法が 提案されている ${ }^{(4)}$ 。分類の基本的な方法として , 相関ルー ルを確信度やサポートを用いてランク付けしておいて, 評 価用のレコードに対して最初に適合した相関ルールを適用 するものがある。しかし，適合するルールがない場合には， デフォルトのクラスになるなどの問題があるため, 分類の 精度を向上する各種の手法が提案されている。Liu ら (11) は, クラス相関ルール (CARs, class association rules) を抽出して分類を行う CBA 法 (classification based on associations) を提案している。CARs は, 連続型属性が あればこれを離散化して整数属性で表されるアイテムとし て扱い, 結論部が分類に用いられる属性に限定された相関 ルールである。指標には, サポートと確信度を用い, 最小 サポートが $1 \%$, 最小確信度が 50 \%以上の CARs を抽出 している。最小サポートの設定は, 分類の特性に強い影響 を与える。值が大きすぎると精度が下がり, 小さすぎると 訓練用データへの過学習を起こしやすくなる。CBA 法で 
は, 確信度の大きなルールから分類ルールを構成する。分 類の評価には, 10-fold cross validations を用いている。こ れはデータベース全体をランダムに 10 分割し，弚のうち 9 グループを訓練用に，残りの 1 グループを評価用に用いる 方法である。この試行を 10 回行い, 平均の誤分類率を算出 する。また，Antonie ら ${ }^{(13)}$ は，確信度が大きい相関ルー ルの集合を作り，対象となるレコードについて相関ルール の条件部をみたすすべてのルールについて分類を行い，各 クラスに分類したルールの確信度を用いた得点を比較して 最終的な分類結果を得る方法を提案している。

\section{GNP を利用した相関ルール抽出と分類}

本章では，GNP を応用して，データベース中に存在す る興味深い相関ルールを抽出し分類問題に適用する方法を 提案する。提案手法においては, 通常の進化論的計算手法 のように最適な個体 (解) を発見するものではなく, 初期 世代から最終世代までの間に，進化を遂げながら存在した 全個体の中から興味深い相関ルールの抽出を実行する。し たがって，特定の世代において個体内部に興味深いルール を数多く含む個体を発見するのではなく，たとえこのよう な個体でも未知の興味深いルールを数多く獲得すべく積極 的に変化をとげていき，このようにして各世代で出現する 興味深いルールを相関ルールライブラリーに蓄積する方式 である。

$\langle 4$ 1 $\rangle$ データベースと相関ルールの抽出 相関ルー ルの前提部を構成する属性 (アイテム) を条件属性，結論 部を構成する属性を目的属性とよぶ。条件属性は 1 または 0 の值をとり，目的属性はクラスに応じた整数值 $(0,1,2$, $\cdots, \mathrm{K})$ をとる。したがって , 対象となるデータベースは表 1 のような形態となる。抽出する相関ルールは, $A_{i}$ を条件 属性， $Z$ を目的属性として，目的属性を特定の $Z$ の属性值 に固定した $\left\ulcorner\left(A_{m}=1\right) \wedge \ldots \wedge\left(A_{n}=1\right) \Rightarrow(Z=C)\right\lrcorner$, $(C=0,1,2, \ldots, K)$ を対象とする。とくに，本論文では条 件属性の属性値を 1 としているが， GNP の遺伝子の設定に よって，属性値が 0 の場合を含めて指定することもできる。

〈4. 2〉 GNP と相関ルールの対応 1つの条件属性を GNP の 1 つの判定ノードで表現する。指定した属性値であ るかどうかを判定し, Yes/Noに 2 分岐する。また，処理 ノードは固有の順番が付けてあり，相関ルールの管理や諸指 標の算出を行う。相関ルールの抽出に用いる GNP の基本構 造を图 3 に示す。図中の $A_{1}=1, A_{2}=1, A_{3}=1$ および $A_{4}=1$ は判定ノードの判定内容を表しており，光れ光れの ノードで指定された条件属性の属性值と目的属性の属性值 を調査する。後述するように, 図 3 のノード接続によって， $\left(A_{1}=1\right) \Rightarrow(Z=C),\left(A_{1}=1\right) \wedge\left(A_{2}=1\right) \Rightarrow(Z=C)$, $\left(A_{1}=1\right) \wedge\left(A_{2}=1\right) \wedge\left(A_{3}=1\right) \Rightarrow(Z=C)$, $\left(A_{1}=1\right) \wedge\left(A_{2}=1\right) \wedge\left(A_{3}=1\right) \wedge\left(A_{4}=1\right) \Rightarrow(Z=C)$ のサポート，確信度および $\chi^{2}$ を算出することができる。こ のように「1つの処理ノードを始点とする一定個数以内の判 定ノードの連結の範囲」で「相関ルールの前提部の集団」を
表現し , データベースのレコード1つずつについて , GNP のノードを処理ノードから順に遷移していく。例えば，あ るレコードについて $A_{1}=1, A_{2}=0$ であれば, $A_{1}=1$ を満たすが， $A_{2} \neq 1$ なので，図 3 において $P_{1}$ から遷移を 始めて $P_{2}$ に達することになる。図 3 の処理ノード $P_{1}$ を通 過したレコード数を $N$ とし，この $N$ 個のレコードのうち， 判定ノード群をYes 側に進んだレコード数を図中の位置で 判定ノードか調査して $a, b, c$ および $d$ とする。ここで, 例 えば, 図 3 で示したレコード数 $b$ のち,さらに目的属性が $\ulcorner Z=1\lrcorner$ となるレコード数 $b(Z=1)$ を調査する。これら $b, b(Z=1)$ が, $\left(A_{1}=1\right) \wedge\left(A_{2}=1\right) \Rightarrow(Z=1) \quad$ につい ての，表 2 における $N x$ および $N z$ に対応し，この相関ルー ルのサポートは $b(Z=1) / N$, 確信度は $b(Z=1) / b$ とな る。同樣に, 図 3 で示したレコード数 $d$ のうち, さらに目的 属性が $\ulcorner Z=1\lrcorner$ となるレコード数 $d(Z=1)$ を調査する。 これら $d, d(Z=1)$ より, $\left(A_{1}=1\right) \wedge\left(A_{2}=1\right) \wedge\left(A_{3}=\right.$ 1) $\wedge\left(A_{4}=1\right) \Rightarrow(Z=1)$ のサポートは $d(Z=1) / N$, 確 信度は $d(Z=1) / d$ となる。判定ノードを No 側に進む場 合は, 探索中の次の順番の処理ノードに接続し，次の判定 ノード群の探索を行うことになる。判定ノードをYes 側に 連続して遷移する場合は，処理ノードから遷移したノード 数が予め指定した個数, すなわち相関ルールの前提部を構 成する属性数の最大に達したら, 判定ノードの判定結果に 関わらず次の順番の処理ノードに接続する。

GNP のノードの接続は, 判定ノードの Yes 側の接続は 必ず判定ノードとし, No 側の接続先は, 探索中の処理ノー ドの次の順番の処理ノードとする。したがって, 同一の判 定ノードに遷移してきても，どの処理ノードに関連したレ コード調査を行っているかによって No 側の接続先の処理 ノードは変わってくる。また, 処理ノードは, 判定ノードに 接続するものとする。これは, 予め判定ノードだけでネット ワークを構成しておき，あとから処理ノードを組み込んだ ことに相当する。判定ノードの Yes 側の接続からなるネッ トワークは, ループを形成していたり, 特定の判定ノード に複数の判定ノードから接続していてもよい。

GNP の探索は, 第 1 番目の処理ノード $P_{1}$ からスタート し，すべての処理ノードについてレコード調査を終えたら レコードを更新し，また $P_{1}$ に戻る。規定のレコードを探索 したら，サポートや確信度， $\chi^{2}$ 值を計算して一世代を終え る。この探索はレコードごとに全個体について平行して進 める。各世代で求まった興味ある相関ルールは, 逐次, 新 規かどうかを判定する。このとき，同一の属性がルール内 で重複して用いられているかどうかの確認を行う。新規の 場合は, サポートや確信度, $\chi^{2}$ 值などの值とともに，世代 間に共通の相関ルールライブラリーに蓄積していく。

〈4 3〉 GNP の適合度＼cjkstart興味深い相関ルールとして， サポートと $\chi^{2}$ 值を用いて，例えば，

$$
\chi^{2}>\chi_{\min }^{2} \ldots \ldots \ldots \ldots \ldots \ldots \ldots \ldots \ldots \ldots \ldots \ldots
$$

support $\geq$ sup $_{\text {min }}$ 


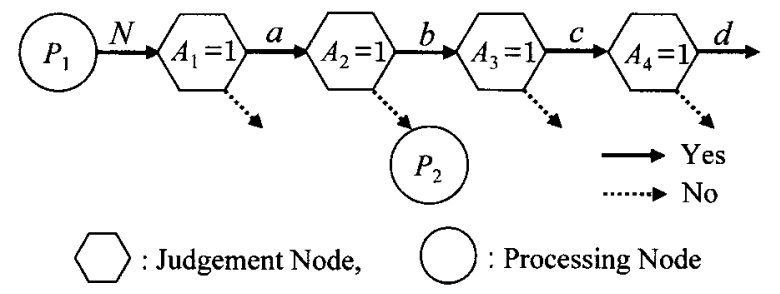

図 3 相関ルールと GNP

Fig. 3. GNP for association rule mining.

の基準を満たす相関ルールを抽出する。ただし， $\chi_{\text {min }}^{2}$ ， $s u p_{\text {min }}$ はユーザが指定する $\chi^{2}$ 値 , サポートの最小值で ある。また，結論部が $Z=C(C=0,1,2, \cdots, K)$ であ るとき, 目的属性が $Z=C$ となるレコードの頻度よりも 相関ルールの確信度が大きい場合のみを抽出する。これら の条件を満たすルールが抽出された時点で, 未抽出である かどうかを判定し，新規の場合には，相関ルールライブラ リーに加える。各個体の適合度 $F$ は , 未抽出の興味深い相 関ルールを次世代において抽出することが期待できる個体 ほど大きな值をもつように設定するため，次のような個体 を高く評価する。

・新規の興味深い相関ルールを抽出できた個体

・新規ではなくても興味深い相関ルールを多く含む個体 また属性数に関しては，

・ルールを構成する属性数が多い興味深い相関ルールを 含む個体ほど高い適合度とする。

こうした観点から，適合度 $F$ には抽出の基準を満たす相関 ルール $i$ の $\chi_{i}^{2}$ 值とルール $i$ の前提部を構成する属性数 $n(i)$ を用いる。また，㚇の相関ルール $i$ がライブラリーにない 場合は，ルール $i$ を次世代に残す価值が高いとして $\alpha_{n e w}$ を加算するものとする。したがって，

$$
F=\sum_{i \in I}\left\{\chi_{i}^{2}+10(n(i)-1)+\alpha_{i_{n e w}}\right\} \cdots \cdots \cdots
$$

を適合度とする。ここで， $I$ は (3) 式かつ $(4)$ 式の興味深 い相関ルールの基準を満足する GNP 個体の相関ルールの 添字の集合である。また，

$$
\alpha_{i_{n e w}}= \begin{cases}\alpha_{n e w} & (\text { ルール } i \text { が新規の場合 }) \\ 0 & (\text { ルール } i \text { が新規でない場合 })\end{cases}
$$

と表される。

〈4. 4〉 GNP の進化 GNP の進化では, 各個体の適 合度の值が大きいものだけを選択する。未抽出の相関ルー ルを獲得するために，選択された全個体について，交叉ま たは突然変異を行う。遺伝子は, 判定ノードの遺伝子群と, 処理ノードの遺伝子群に区分して，关れ光れのノード群内 で交叉と突然変異の操作を行う。突然変異には，ノードの 接続先をランダムにかえる突然変異 1 と, 判定ノードの属 性を別の属性に交換する突然変異 2 の 2 通りを考える。特
に後者は, 興味深い相関ルールが抽出されたときに, 例え ば前提部の属性を変えたルールの評価を行うことを可能に する。なお, 突然変異や交叉による接続先の変更は, 前世 代の個体内に存在する興味深い属性の組合せの一部を組み かえて新しいルールの候補を作り出すことに対応する。適 合度によって, 上位 $1 / 3$ の個体を選択し，光れらを 3 個ず つ再生し, 交叉, 突然変異 1 および突然変異 2 の 3 種類の 遺伝子操作を行う。

進化の操作方法について，GNP の個体数が 120 の場合 について，具体例をあげて説明する。120 個体中，適合度 の高い 40 個体をランク付けして選出し , 各個体を 3 個ず つ再生する。光の後, 交叉, 突然変異 1 (接続先の変更), 突然変異 2 (ノードの交換) により各 40 個体, 計 120 個体 を形成する。交叉は, 判定ノードの遺伝子群について 40 個体を 20 組として一樣交叉を確率 $P_{c}$ で行う。突然変異に ついては次のように行う。判定ノードの遺伝子群について は, 突然変異 1 の発生確率 $P_{m 1}$ は $1 / 3$, 突然変異 2 の発生 確率 $P_{m 2}$ は $1 / 5$ が標準的な値とする。突然変異 1 , 突然変 異 2 の発生確率は抽出される相関ルールを構成する属性の 個数を考慮して定めることができる。これらの発生確率の 設定により, 探索的なルールの抽出を行うか, 既に抽出さ れたルールの一部の属性を変更した精査的な抽出を行うか を調節できる。なお, 処理ノードの遺伝子群については突 然変異 1 を確率 1 で行い, 接続先をランダムに決定する。

〈4 5〉レコードの分類 GNP を用いて結論部の属性 を指定した興味深い相関ルールを抽出した場合, 抽出され たルールを用いて未知のレコードを分類する (目的属性 Z の値を予想する) 方式を以下に示す。

- (方式 $1($ Method 1))

1) 結論部が $Z=C(C=0,1,2, \cdots, K)$ である相関 ルールの個数 $\operatorname{total}(C)$ を求める。

2) 結論部が $Z=C(C=0,1,2, \cdots, K)$ である相関 ルールのうち, 対象レコードがルールの前提部を満た す相関ルールの個数 agree $(C)$ を求める。

3) $Z=C$ と分類する相関ルール数に関する割合 $\operatorname{agree}(C) / \operatorname{total}(C)$ を計算し，この值が最大となる $C$ の值を用いて, 対象となるレコードを $Z=C$ と分類 する。(割合に等しいものがある場合は, 予め設定した 優先順位により分類する。)

- (方式 2(Method 2))

1) 結論部が $Z=C(C=0,1,2, \cdots, K)$ である相関 ルールの個数 $\operatorname{total}(C)$ を求める。

2) 前提部を構成する属性数が $m$ 個である相関ルール $\left(A_{j_{1}}=1\right) \wedge \ldots \wedge\left(A_{j_{m}}=1\right) \Rightarrow(Z=C)$ と評価の対 象となるレコードの距離 $D$ を以下のように定める。レ コードの属性值について, 属性值が $A_{j_{k}}=1$ となる属 性が $t$ 個あるとき，属性值が $A_{j_{k}} \neq 1$ となる属性は， $m-t$ 個ある。ただし, $1 \leq k \leq m$ である。これらを 用いて,$D=\max \{\{t-(m-t)\} / m, 0\}$ とする。

3) 結論部が $Z=C$ である相関ルールについて対象レ 
コードとの距離 $D$ を求め, これらの和を $D \operatorname{sum}(C)$ と する。

4) $Z=C$ と分類する相関ルール数に関する割合 $\operatorname{Dsum}(C) / \operatorname{total}(C)$ を計算し，この值が最大となる $C$ の值を用いて，対象となるレコードを $Z=C$ と分 類する。(割合に等しいものがある場合は，予め設定し た優先順位により分類する。）

\section{5. シミュレーション}

本章では，UCI ML Repository ${ }^{(14)}$ のデータを用いて， GNP を用いて抽出された相関ルールを用いた分類法の有 効性の検討を行う。

〈5 1 1 設 定 データベースの属性のうち, 連続 值をとるものについては相互情報量 ${ }^{(2)}$ を用いて 2 つの值 (0 または 1$)$ に離散化して新たな属性 (アイテム) とし，カ テゴリ型の属性についてはカテゴリごとに新たな属性 (ア イテム) を作ることで，属性值が 1 または 0 からなる相関 ルール抽出用のデータベースに変換する。データベースの レコードを 10 組に分け，このうち 9 組を訓練用データとし， 残り 1 組を評価用データとして，10-fold cross validations を行う。

興味深い相関ルール抽出にあたり，興味深さの指標は $\chi_{\text {min }}^{2}=6.63$ かつ $\sup _{\min }=0.05$ とし, 相関ルールの 前提部を構成する属性の個数 $n(i)$ は $1 \leq n(i) \leq 8$ とす る。GNP の 1 個体中の判定ノードの個数は 75 個，処理 ノードの個数は 10 個とし, GNP の個体数は 120 個 , 終了 世代数 500 世代とする。また, 突然変異確率 $P_{m 1}=1 / 3$, $P_{m 2}=1 / 5$, 交叉確率 $P_{c}=1 / 5$ を用い， $\alpha_{n e w}=150$ と する。

実験に用いるデータセットを以下に示す。

- cleveland

心臓病に関するデータセットである cleveland は, 条 件属性となる属性が 13 個であり，目的属性は，心臟病 にかかわる危険度を表している。データセットのうち， 各属性値に洩れのない 297 個のレコードを用いる。13 個の条件属性からなるデータセットを 25 個の条件属性 (属性值が 1 または 0 ) からなるデータベースに変換す る。また, 目的属性 $(Z)$ は，心藏病である $(Z=1)$, ま たは，心藏病でない $(Z=0)$ の 2 つ值をとる。 $Z=1$ を優先のクラスとする。

- breast-w

乳がんに関するデータセットである breast-w は, 条件 属性となる属性が 9 個であり弚れ光れの属性値が 10 段 階の数值をとる。目的属性は, 乳がんに関して悪性か 良性かのいずれかを表している。データセットのうち， 各属性值に洩れのない 683 個のレコードを用いる。9 個の条件属性からなるデータセットを 18 個の条件属 性 (属性值が 1 または 0$)$ からなるデータベースに変換 する。また，目的属性 $(Z)$ は，悪性 $(Z=1)$, または, 良性 $(Z=0)$ の 2 つの値をとるものとした。 $Z=1$ を
優先のクラスとする。

〈5. 2〉 結果と考察 訓練用データから抽出された全 ルールを用いて評価用データのレコードを分類した場合の 平均の誤分類率を表 3 に示す。表 3 において，抽出された 全ルールを用いた場合を all, 確信度が 0.8 以上の相関ルー ルの集合を用いた場合を 0.8 , 確信度が 0.9 以上の相関ルー ルの集合を用いた場合を 0.9 と表している。なお，表 3 に おける $C B A, c 4.5$ は文献(11) における結果を参考として 示したものである。表 3 の結果から提案手法の分類精度は 従来手法と同程度か乥れ以上であると評価できる。抽出さ れた興味深い相関ルールの中で, さらに確信度の最小值に より分類に用いる相関ルールに制限を加えると, 誤分類率 に差がみられる。とくに, cleveland では, 最小確信度を 設定したルールの集合を用いた場合には, 分類の誤りが多 くなる。医療系のデータの場合には, データに個人差があ ることなどから厳密すぎるルールのみを用いることは適当 でない可能性が指摘できる。

表 4 は, 分類に用いる相関ルールの数を変えた場合の分 類結果である。プールに抽出された順番に相関ルールに番 号を付け，10 番目，30 番目，100 番目，300 番目および 1000 番目までの相関ルールを分類に用いている。また，all は抽出されたすべての相関ルールを用いた場合である。 300 個のルールを用いれば，すべてのルールを用いた場合と同 樣の誤分類率となることがわかる。

表 5 は, 表 4 で用いた相関ルールを抽出するのに要した平 均計算時間を示したものである。プールに 300 番目のルー ルが抽出されるまでに要する時間は, $\operatorname{cleaveland}(Z=1$ の 場合) で 0.43 秒, breast- $w$ ( $Z=0$ の場合) で 1.4 秒程度で あり, 短時間で分類に用いるルールが獲得されていること がわかる。GNPを用いた興味深い相関ルールの抽出では， ユーザの設定した興味深さの指標を満たすすべてのルール を抽出することはできないが, ユーザの目的に十分と考え られるルールを効率よく短時間て獲得できる。

表 6 は, 抽出された相関ルールのうち, 前提部を構成す る属性数が 7 個または 8 個のもののみを抽出された順番に 応じて用いた場合の誤分類率を示したものである。方式 1 では, 分類に用いる相関ルール数が少ないと, 評価用のレ コードを分類することができずデフォルトのクラスに分類 することが多くなるために誤分類率が大きくなっている。 これに対し，方式 2 ではルール数が少なくても有効に分類 できていることがわかる。いずれの方式においても，分類 に用いる相関ルールの数が多くなると, 誤分類率は小さく なっている。

提案手法では, 抽出されたルールすべてが, 興味深さの 指標を満たすものであり，すでに分類のための根拠をもつ ている。このため, 従来手法と異なり分類に適した相関ルー ルの集合を新たに構成する必要がない。GNP を用いたルー ル抽出では，すべてのルールを抽出することはできないが， 与えられた時間 (世代数) で抽出できたルールだけを用いて 分類することができるため, 短時間で相関ルール抽出から 
表 3 確信度の最小値の基準の有無による分類結果 (誤分類率 (\%))

Table 3. Classification results versus threshold of confidence (Error rates (\%)).

\begin{tabular}{|c|c|c|c|c|c|c|c|c|}
\hline & \multicolumn{3}{|c|}{ Method 1} & \multicolumn{3}{|c|}{ Method 2} & \multirow[t]{2}{*}{$C B A$} & \multirow[t]{2}{*}{$c 4.5$} \\
\hline & all & 0.8 & 0.9 & all & 0.8 & 0.9 & & \\
\hline cleveland & 17.7 & 17.7 & 18.3 & 16.3 & 17.3 & 17.7 & 16.7 & 18.2 \\
\hline breast-w & 3.2 & 3.4 & 3.5 & 3.4 & 3.5 & 3.5 & 3.9 & 3.9 \\
\hline
\end{tabular}

表 4 分類に用いるルール数による分類結果 (誤分類率 ( \% ))

Table 4. Classification results versus number of rules (Error rates (\%)).

\begin{tabular}{|c|c|c|c|c|c|c|c|c|c|c|c|c|}
\hline & \multicolumn{6}{|c|}{ Method 1} & \multicolumn{6}{|c|}{ Method 2} \\
\hline & 10 & 30 & 100 & 300 & 1000 & all & 10 & 30 & 100 & 300 & 1000 & all \\
\hline cleveland & 30.3 & 19.3 & 18.3 & 18.0 & 17.3 & 17.7 & 27.3 & 19.7 & 18.0 & 17.0 & 17.0 & 16.3 \\
\hline breast-w & 4.1 & 4.1 & 3.4 & 3.1 & - & 3.2 & 4.1 & 3.7 & 3.4 & 3.4 & - & 3.4 \\
\hline
\end{tabular}

表 5 ルール抽出に要した平均計算時間 (秒)

Table 5. Averaged run-time versus number of extracted rules in the pool (sec).

\begin{tabular}{l|c|c|c}
\hline & 100 & 300 & 1000 \\
\hline cleveland $(Z=1)$ & 0.13 & 0.43 & 1.63 \\
cleveland $(Z=0)$ & 0.14 & 0.41 & 1.60 \\
breast $-w(Z=1)$ & 0.39 & 1.14 & - \\
breast $-w(Z=0)$ & 0.35 & 1.38 & - \\
\hline
\end{tabular}

表 6 属性数の多いルールを用いた場合の分類結果 (誤分類率 ( \% ))

Table 6. Classification results using long rules (Error rates (\%)).

\begin{tabular}{|c|c|c|c|c|c|c|c|c|c|c|}
\hline & \multicolumn{5}{|c|}{ Method 1} & \multicolumn{5}{|c|}{ Method 2} \\
\hline & 10 & 30 & 100 & 300 & all & 10 & 30 & 100 & 300 & all \\
\hline cleveland & 34.7 & 28.3 & 22.0 & 21.0 & 19.7 & 18.3 & 18.0 & 19.7 & 19.0 & 19.0 \\
\hline breast-w & 8.2 & 5.3 & - & - & 4.1 & 3.5 & 3.2 & - & - & 3.5 \\
\hline
\end{tabular}

分類まで行うことが可能になる点は提案手法の特徵である。 また , 分類の対象となるレコードのデータの一部が欠落し ていても用いることが可能である。提案手法では，最小サ ポートを $5 \%$ として相関ルールを抽出しているが，CBAな どの従来手法では $1 \%$ となっている。このため, 提案手法 の方が, 過学習による影響が小さくなるなど , 分類に用い ているルールの信頼性が高いと考えられる。従来手法との 比較については, 他の病気に関するデータセットを用いて さらに検討していきたい。

シミュレーションにおいては, 抽出された興味深いルー ルを用いた分類手法を検討したが , とくに個々のルールに ついての考察は行っていない。シミュレーションで抽出さ れた各ルールの前提部は, 患者 (悪性) と正常者 (良性) に 対して興味深い差異をもった属性の組合せであり，これら を解析することで新規の知見を獲得することが期待できる。 提案手法は, 興味深いルールの抽出, 新規の知見の獲得を目 的として用いることもできる。提案手法の特徵として， $\chi^{2}$ 値を指標に用いており, 密なデータベースに適用できるた め, 従来手法では困難と考えられていた医療系のルール抽
出にとくに有効であると考えられる。例えば, 特定の疾患 に関する患者と正常者についての遺伝子多型に関するデー タセットから, どの遺伝子多型の組合せが炎の疾患に関与 しているかというようなデータマイニングへの適用が考え られる。

\section{6. まとめ}

遺伝的ネットワークプログラミングを用いた相関ルール抽 出法による医療関連データベースからの興味深い相関ルー ル抽出と抽出されたルールの有効性を検討した。本研究で 用いた相関ルール抽出法は, 興味深さの指標に統計学で用 いられる $\chi^{2}$ 值を用いており, 密なデータベースからの相 関ルール抽出が可能であるなど医療分野のデータベースへ の応用に適していると考えられる。本論文では, 結論部の 属性を固定して抽出した相関ルールを用いたレコード分類 法を提案した。今後は, 多くの実際のデータベースに興味 深い相関ルールの抽出とこれを用いた分類を展開していく 予定である。

(平成 17 年 10 月 24 日受付, 平成 18 年 2 月 28 日再受付) 


\section{文献}

(1) C. Zhang and S. Zhang: "Association Rule Mining: models and algorithm", Springer (2002)

( 2 ) T. Fukuda, Y. Morimoto, and T. Tokuyama: "Data Mining", Kyoritsu Shuppan (2001) (in Japanese)

福田岡志·森本康彦·德山 豪: データマイニング, 共立出版 (2001)

( 3 ) R. Agrawal and R. Srikant: "Fast Algorithms for Mining Association Rules", In Proc. of the 20th VLDB Conf., Santiago, Chile, pp.487-499 (1994)

(4) R.J. Bayardo Jr., R. Agrawal, and D. Gunopulos: "Constraint-Based Rule Mining in Large, Dense Databases", In Proc. of the 15th Int. Conf. on Data Eng., pp.188-197 (1999)

( 5 ) S. Brin, R. Motwani, and C. Silverstein: "Beyond market baskets: generalizing association rules to correlations", In Proc. of ACM SIGMOD, pp.265-276 (1997)

(6) T. Eguchi, K. Hirasawa, J. Hu, and N. Ota: "A Study of Evolutionary Multiagent Models Based on Symbiosis", IEEE Trans. on Syst., Man and Cybernetics -PART B-, Vol.35, No.1, pp.179-193 (2006)

( 7 ) H. Katagiri, K. Hirasawa, J. Hu, and J. Murata: "Network Structure Oriented Evolutionary Model - Genetic Network Programming", In Proc. of Genetic and Evolutionary Computation Conference, pp.219-226 (2001)

(8) K. Hirasawa, M. Okubo, H. Katagiri, J. Hu, and J. Murata: "Comparison between Genetic Network Programming and Genetic Programming using evolution of ant's behaviors", Trans. IEE Japan, Vol.121-C, No.6, pp.1001-1009 (2001) (in Japanese)

平澤宏太郎・大久保雅文・片桐広伸・胡 敬炉・村田純一：「蟻の 行動進化における Genetic Network Programming と Genetic Programming の性能比較」, 電学論 C , 121, 6, pp.1001-1009 (2001)

(9) K. Shimada, K. Hirasawa, and T. Furuzuki: "Association rule mining using genetic network programming", The 10th Int. Symp. on Artificial Life and Robotics 2005, pp.240-245 (2005)

(10) K. Shimada, K. Hirasawa, and J. Hu: "Genetic Network Programming with Association Rule Acquisition Mechanisms", SICE Annual Conference 2005, pp.13-19 (2005)

(11) B. Liu, W. Hsu, and Y. Ma: "Integrating Classification and Association Rule Mining", In Proc. of ACM Int. Conf. on Knowledge Discovery and Data Mining, pp.80-86 (1998)

(12) M.S. Chen and P.S. Yu: "An Effective Hash-Based Algorithm for Mining Association Rules", In Proc. of the 1995 ACM SIGMOD Conf., pp.175-186 (1995)

(13) M-L. Antonie and O.R. Zä̈ane: "An Associative Classifier based on Positive and Negative Rules", In Proc. of DMKD, Paris, France, pp.64-69 (2004)

(14) C. Blake and C. Merz: UCI repository of machine learning databases.

http://www.ics.uci.edu/ mlearn/MLRepository.html.

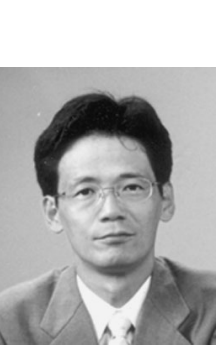

香 (学生員) 1986 年早稲田大学理工学部応用物理 学科卒業。1999 年筑波大学大学院修士課程医科 学研究科医科学専攻修了。現在, 早稲田大学大学 院情報生産システム研究科博士後期課程在学中。

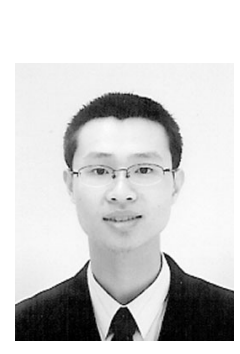

(非会員) 2003 年中国上海交通大学外国語学院 日本語学科卒業。2005 年早稲田大学大学院情報 生産システム研究科修士課程修了。

平 澤 宏太郎

(正員) 1964 年九州大学工学部電気工学科卒業。 1966 年同大学大学院工学研究科修士課程電気工 学専攻修了。工学博士。同年 (株) 日立製作所入 社 日立研究所勤務, 1989 年 8 月同研究所副所長。 1991 年 8 月同大みか工場主管技師長。92 年 12 月九州大学工学部教授。1996 年 5 月同大学院シ ステム情報科学研究科教授, 2000 年同大学大学 院システム情報科学研究院教授。2002 年 9 月早 稲田大学大学院情報生産システム研究科教授, 現在に至る。計測自動 制御学会, 情報処理学会, IEEE 各会員。

古 月 敬 之 (正員) 1986 年中国中山大学大学院修士修了。同

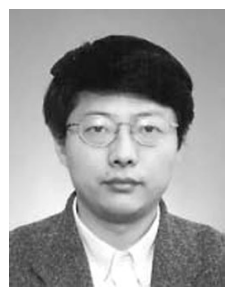
年, 同大学電子工学科助手, 1988 年同講師, 1993 年来日, 1997 年九州工業大学情報工学研究科博 士後期課程修了。博士 (情報工学)。同年九州大学 ベンチャービジネスラボラトリ非常勤研究員を経 て, 同大学システム情報科学研究科助手, 2000 年 同大学大学院システム情報科学研究院助手, 2003 年早稲田大学大学院情報生産システム研究科助教 授, 現在に至る。計測自動制御学会会員。 